\title{
Accumulation of copper by the aquatic macrophyte Salvinia biloba Raddi (Salviniaceae)
}

\author{
F. Freitas ${ }^{a}$, S. Lunardi ${ }^{b}$, L. B. Souza ${ }^{b}$, J. S. C. von der Osten ${ }^{a}$, R. Arruda, \\ R. L. T. Andrade and L. D. Battirola ${ }^{a, c}$ \\ aPrograma de Pós-graduação em Ciências Ambientais, Universidade Federal de Mato Grosso - UFMT, \\ Câmpus Universitário de Sinop, CEP 78557-267, Sinop, MT, Brazil \\ 'Instituto de Ciências Agrárias e Ambientais, Universidade Federal de Mato Grosso - UFMT, \\ Câmpus Universitário de Sinop, CEP 78557-267, Sinop, MT, Brazil \\ 'Instituto de Ciências Naturais, Humanas e Sociais, Universidade Federal de Mato Grosso - UFMT, \\ Câmpus Universitário de Sinop, CEP 78557-267, Sinop, MT, Brazil \\ *e-mail: francieledfreitas@gmail.com
}

Received: July 08, 2016 - Accepted: September 12, 2016 - Distributed: February 28, 2018

(With 2 figures)

\begin{abstract}
Aquatic macrophytes have properties and mechanisms which are useful for the removal of substances in solution, commonly used in phytoremediation processes in aquatic environments. This study evaluated the performance of copper (Cu) accumulation by Salvinia biloba Raddi (Salviniaceae) in different metal concentrations (1, 3 and $\left.5 \mu \mathrm{g} \mathrm{mL}{ }^{-1}\right)$, as well as the control treatment, measured at intervals of 0,7 and 14 days under laboratory conditions, with control as to $\mathrm{pH}$ and luminosity. After the experiment, the $S$. biloba biomass was washed, kiln dried, crushed and subjected to the process of digestion, and subsequently the accumulated copper content was determined by atomic absorption spectroscopy. The results showed that $S$. biloba is apt at accumulating copper, varying significantly between different treatments and days of exposure to the contaminant, as well as its interaction (treatment $\times$ days). The highest accumulation values were observed in treatment with $5 \mu \mathrm{g} \mathrm{mL}-1$, which at 14 days, with 11,861 $\mu \mathrm{g}$ g-1 of copper. We observed symptoms of toxicity and mortality in plants, probably indicating the effect of copper on the species when at high levels. Salvinia biloba is an efficient species in the removal of copper in solution, its recommendation as a remediating agent in aquatic ecosystems being possible.
\end{abstract}

Keywords: aquatic ecosystems, phytoremediation, aquatic plants, bioaccumulation, water resources.

\section{Acumulação de cobre pela macrófita aquática Salvinia biloba Raddi (Salviniaceae)}

\section{Resumo}

Macrófitas aquáticas apresentam propriedades e mecanismos úteis à remoção de substâncias presentes em solução, comumente, utilizadas em processos de fitorremediação de ambientes aquáticos. Este estudo avaliou o desempenho de acumulação de cobre $(\mathrm{Cu})$ por Salvinia biloba Raddi (Salviniaceae) em diferentes concentrações do metal (1, 3 e $\left.5 \mu \mathrm{g} \mathrm{mL}^{-1}\right)$, além do tratamento controle, avaliados em intervalos de 0,7 e 14 dias, sob condições laboratoriais, com controle de $\mathrm{pH}$ e luminosidade. Após o experimento a biomassa de $S$. biloba, foi lavada, seca em estufa, triturada e submetida ao processo de digestão, sendo, posteriormente, o teor de cobre acumulado determinado por espectroscopia de absorção atômica. Os resultados evidenciaram que S. biloba é hábil em acumular cobre em sua biomassa, variando significativamente entre os diferentes tratamentos e dias de exposição ao contaminante, bem como por sua interação (tratamentos $\times$ dias). Os maiores teores de acúmulo foram observados no tratamento com $5 \mu \mathrm{g} \mathrm{mL} \mathrm{mL}^{-1}$, que aos 14 dias apresentou até $11.861 \mu \mathrm{g} \mathrm{g}^{-1}$ de $\mathrm{Cu}$. Observamos sintomas de toxicidade e mortalidade nas plantas, evidenciando, provavelmente, o efeito do cobre sobre a espécie quando em elevados níveis. Salvinia biloba é uma espécie eficiente na remoção do cobre em solução, sendo possível sua recomendação como agente de remediação em ecossistemas aquáticos.

Palavras-chave: ecossistemas aquáticos, fitorremediação, plantas aquáticas, bioacumulação, recursos hídricos. 


\section{Introduction}

The use of plants and microorganisms is an important tool in the removal processes of different classes of pollutants in aquatic and terrestrial ecosystems (Farnese et al., 2014; Pio et al., 2013). Traditional methods of removing heavy metals from effluent, when at low concentrations, may be expensive and present very little selectivity and yield (Silva et al., 2014). In contrast, remediation with biomass is an efficient technology as it usually uses abundant species, which are biodegradable and economically viable (Pitol-Filho, 2011).

In freshwater or continental ecosystems, macrophytes have favorable characteristics for their use as potential agents of remediation or as bio-indicators of environmental impact (França et al., 2014; Maroneze et al., 2014; Rocha et al., 2012), such as their wide distribution, performance in the food chain, natural filtering of pollutants and nutrient cycling of these environments (Esteves, 1998; Medeiros et al., 2016). They may present fixed and free floating biological forms, submerged fixed and free, emerging, amphibious or epiphytes (e.g. Pott and Pott, 1997; Pott et al., 2011).

Aquatic macrophytes of South American tropical environments develop throughout the year, due to favorable thermal and light regime (Pompeo, 2008) and are able to accumulate metal ions, removing them from the solution by means of bio-sorption and bioaccumulation processes (Oliveira, 2012; Schneider et al., 2011). A good example of this are the Salviniaceae (Pteridophyta), represented by species of Salvinia Ség. and Azolla Lam. (Tryon and Tryon, 1982). These plants are floating aquatic macrophytes, originating in South America, acaules, rhizomatous and, under favorable conditions, form an enormous vegetative mass on the water surface (Pitelli et al., 2014), especially Salvinia recognized by verticillate fronds, of which two are floating, whole and green and one submerged, with many divisions, like a no chlorophyll root (Prado, 2006). Among the most common species $S$. auriculata Aubl., S. minima Baker, S. natans (L.) All. and S. biloba Raddi stand out.

Studies on S. biloba are scarce, however, results obtained with other species of the same genus report the effectiveness of these macrophytes as regards to the removal of toxic metals from aquatic biota (Dhir et al., 2008; Guimarães et al., 2012; Wolff et al., 2009, 2012). These elements resulting from industrial, agricultural, mining and domestic sewage activities directly impact the water bodies when they do not receive appropriate treatment and are inadequately disposed of in the environment. So, in this study we evaluate the performance of $S$. biloba as a possible phytoremediation in contaminated aquatic environments, taking its potential in the accumulation of copper in the biomass as a parameter, (i) depending on the concentration of contaminant agent in the environment; (ii) with regards to the time of exposure to the contaminant, and (iii) the relationship between the concentration of the contaminant and exposure time under laboratory conditions.

\section{Material and Methods}

\subsection{Study area}

The $S$. biloba samples were collected manually in August 2014 in a pond in the urban area of Alta Floresta, Mato Grosso, Brazil (0952'32" S and 56 $05^{\circ} 10^{\prime}$ ' W). During collection the plants were stored in coolers and sent to the Laboratório Integrado de Pesquisas Químicas (LIPEQ), Universidade Federal de Mato Grosso, Câmpus Universitário de Sinop, where the experiment was carried out.

\subsection{Laboratory procedures}

In the laboratory the plants were washed in running water and packed in 12 containers containing $30 \mathrm{~L}$ of water. A nutrient cultivation solution was added to these containers, consisting of $240 \mathrm{~mL}$ of $\left(1 \mathrm{~mol} \mathrm{~L}^{-1}\right)$ solution of $\left(\mathrm{NH}_{4}\right)_{2} \mathrm{CO}_{3}$ (Ammonium Carbonate) and $90 \mathrm{~mL}$ of $\left(1 \mathrm{~mol} \mathrm{~L}^{-1}\right.$ ) solution of $\mathrm{K}_{2} \mathrm{HPO}_{4}$ (Dibasic Potassium Phosphate), as well as $\mathrm{KH}_{2} \mathrm{PO}_{4}$ (Monobasic Phosphate) for $\mathrm{pH}$ buffering between 6.5 and 7.0, similar to the $\mathrm{pH}$ of the collecting area. Dissolved copper sulfate was used for the infection process (in $\mu \mathrm{g} \mathrm{mL}^{-1}$ ) according to the different treatments $\left(1,3\right.$ and $5 \mu \mathrm{g} \mathrm{mL}^{-1}$ of copper). The different copper concentrations were defined based on the values established by Resolution CONAMA 357/2005 (Brasil, 2005) (Class I - freshwaters), and the concentrations used were above the acceptable set value, characterizing contamination of the environment.

In each container 60 specimens of $S$. biloba were cultivated. These containers were divided into 4 treatments represented by different concentrations of copper contamination (1, 3 and $5 \mu \mathrm{g} \mathrm{mL}^{-1}$ of copper) and the control treatment (0 $\mu \mathrm{g} \mathrm{mL}^{-1}$ of copper), totaling 3 replicates for each concentration. The whole experiment was conducted in laboratory conditions $\left( \pm 25^{\circ} \mathrm{C}\right)$, with $\mathrm{pH}$ control of water using bench $\mathrm{pH}$ meter (6.5 and 7.0) and light (10 hours light per day, with automatic control).

The removal of the plants for analysis took place at 0,7 , and 14 days. The plants referring to day " 0 " of the experiment were analyzed as they arrived from the field, presenting the conditions that they had in their environment. Due to the reduced size, $5 \mathrm{~S}$. biloba plants were considered as a sampling unit, considering the amount of biomass needed for the analysis. Thus, at each interval (0, 7 and 14 days), three sets of 5 subjects in each treatment were used for the analysis. After removal, the plants remained in the kiln/greenhouse at a temperature of $70{ }^{\circ} \mathrm{C}$ for drying until reaching constant weight, and then thoroughly grinded.

To determine the cumulative total copper content in the plant biomass, 0.2 grams of dried and ground mass of each sample were digested in acid-oxidant (e.g. Hseu, 2004). Each sample was placed in a test tube to which $7 \mathrm{~mL}$ of sulfuric acid P. A. $\left(\mathrm{H}_{2} \mathrm{SO}\right)$ is added. After $1 \mathrm{~h}$, $3 \mathrm{ml}$ of hydrogen peroxide P. A. $\left(\mathrm{H}_{2} \mathrm{O}_{2}\right)$ is added. After this process, the tubes were heated in a block digester at $250^{\circ} \mathrm{C}$ for $2 \mathrm{~h}$, after which they are cooled and receive four $\mathrm{mL}$ of $\mathrm{H}_{2} \mathrm{O}_{2}$. The final solutions which were obtained were diluted in water and transferred to $25 \mathrm{~mL}$ volumetric flasks. 
The copper content present was determined by atomic absorption spectroscopy with flame atomization in Varian equipment, model AA140. The standard solution used for the calibration curve was traceable to NIST (National Institute of Standards and Technology) of the Specsol brand.

\subsection{Statistical analysis}

So as to determine the existence of significant average differences in the accumulation of copper between the different days of the experiment $(0,7$ and 14 days $)$ and the different concentrations of the pollutant $\left(0,1,3\right.$ and $5 \mu \mathrm{g} \mathrm{mL}^{-1}$ of $\left.\mathrm{Cu}\right)$ an ANOVA model was elaborated. Both effects "days of experiment" and "concentration of pollutant" were considered as fixed effects. Due to the fact that the variable "days of experiment" is a qualitative variable, a regression model was not built; however, so as to assess the tendency of accumulation as a function of time, a nonparametric trend line was adjusted. All models and figures were built in an $\mathrm{R}$ environment ( $\mathrm{R}$ Core Team, 2014).

\section{Results}

We noted that $S$. biloba presented high values of copper accumulation. The plants exposed to concentration of $5 \mu \mathrm{g} \mathrm{mL}^{-1}$ of the contaminant had higher performance and extent of absorption, particularly in the second week of the experiment (14 days), with accumulation levels of up to $11,861 \mu \mathrm{g} \mathrm{g}^{-1}$, showing an increase in the concentration of the metal in the biomass up to 950 fold in relation to the levels found in the samples at time zero $\left(0 \mu \mathrm{g} \mathrm{mL}^{-1}=12.47 \mu \mathrm{g} \mathrm{g}^{-1}\right)$ depending on the specimen being analyzed (Figure 1).

In plants exposed to contamination with $5 \mu \mathrm{g} \mathrm{mL}^{-1}$ the uptake of metal was increasing during the course of the days of the experiment, reaching high levels of accumulation in the first $\left(4,076 \mu \mathrm{g} \mathrm{g}^{-1}\right)$ and second $\left(11,861 \mu \mathrm{g} \mathrm{g}^{-1}\right)$ weeks, respectively (Figure 2). This tendency was also observed in plants exposed to $3 \mu \mathrm{g} \mathrm{mL}^{-1}$ concentration of the contaminant with high accumulation levels in both the first $\left(3,004 \mu \mathrm{g} \mathrm{g}^{-1}\right)$ and the second week $\left(9,039 \mu \mathrm{g} \mathrm{g}^{-1}\right)$ (Figure 2), presenting an accumulation of up to 725 fold more compared to zero time.

The copper content in the biomass of the plants subjected to the treatment with a concentration of $1 \mu \mathrm{g} \mathrm{mL}^{-1}$ of copper presented little variation between the first and second weeks. During the first week the greatest accumulation was $943 \mu \mathrm{g} \mathrm{g}^{-1}$ of $\mathrm{Cu}$, demonstrating a concentration 75 fold higher with respect to zero time, while in the second week there was relative stagnation in absorption at concentrations of up to $814 \mu \mathrm{g} \mathrm{g}^{-1}$ of $\mathrm{Cu}$ (Figure 2). The samples of $S$. biloba evaluated in the control treatment presented no fluctuation in accumulation values during the experiment and showed an initial minimum amount of copper present in the plant biomass, at around $12.43 \mu \mathrm{g} \mathrm{g}^{-1}$ of $\mathrm{Cu}$.

Significant variations were observed in relation to treatment with different concentrations of copper $\left(\mathrm{F}_{3,66}=245.69\right.$; $\mathrm{P}<0.0001$ ), with variation between treatments with 3 and $5 \mu \mathrm{g} \mathrm{g}^{-1}$ of $\mathrm{Cu}$ compared to control (Tukey HSD, P $<0.0001)$. The control treatment did not present any variation in relation to the samples submitted to the concentration of 1 ppm (Tukey HSD, $P=0.07$ ). The exposure time of the plants to the contaminant also showed a significant variation $\left(\mathrm{F}_{2,66}=155.16 ; \mathrm{P}<0.0001\right)$ with an increase in accumulation over time. Thus, the interaction between the concentration of the contaminant and the exposure time also varied significantly $\left(\mathrm{F}_{6,66}=50.28 ; \mathrm{P}<0.0001\right)$, indicating that the degree of concentration of the accumulated copper in the samples is associated with the time of exposure to the contaminant, as well as its concentration.

As from the $5^{\text {th }}$ day of the experiment we observed that some plants presented changes in color, texture and lesions in the floating leaves. Possibly, these bad morphological conditions, which intensified in the following days, caused the death of plants, recorded both in the treatments with the contaminant and in the control treatment until the $14^{\text {th }}$ day.

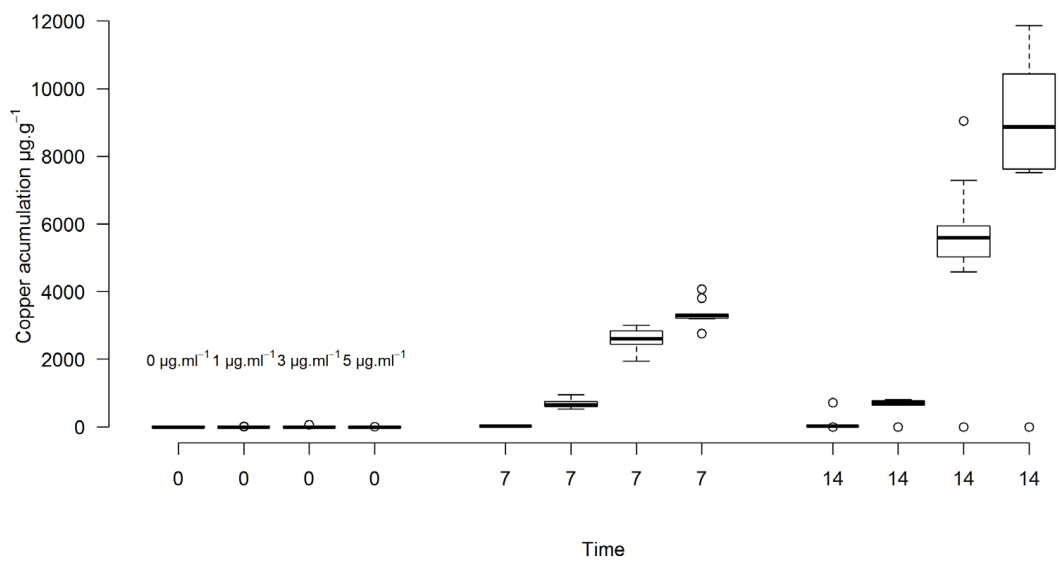

Figure 1. Accumulation of copper in the $S$. biloba biomass over 14 days of the experiment according to the analysis carried out at 0,7 and 14 days with concentrations of $0,1,3$ and $5 \mu \mathrm{g} \mathrm{mL} \mathrm{m}^{-1}$ of copper. 

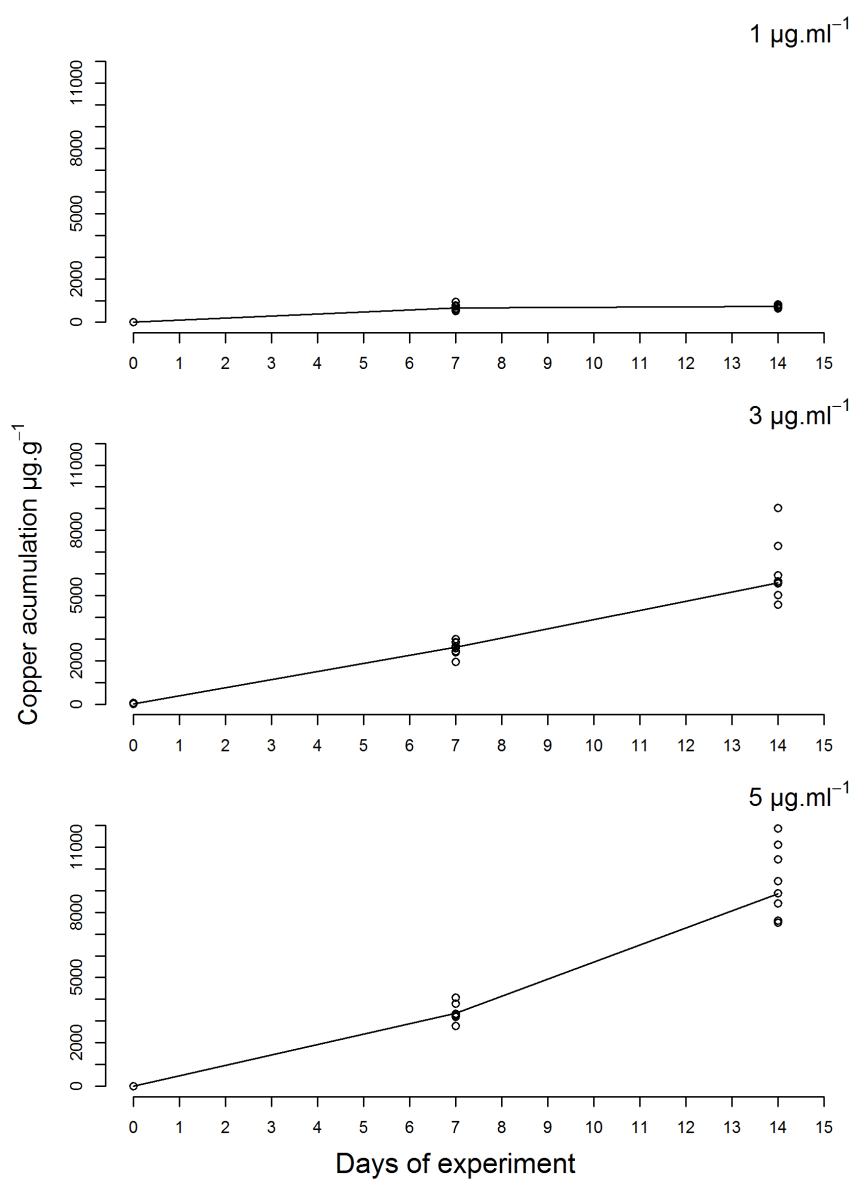

Figure 2. Variation in copper accumulation rate throughout the experiment, differentiated by the metal concentrations in the $S$. biloba biomass.

\section{Discussion}

The aquatic macrophyte Salvinia biloba presented high values of copper accumulation. This accumulation was greatest when the plants were submitted to the presence of greater concentrations of the contaminant, with an increase in absorption over the experimental period (time of exposure to contaminants), showing that the species is effective in removing metal in solution. Greater concentrations of the metal in the solution also caused greater bioaccumulation levels as a result of the availability of metal ions to the assimilation processes of the plant, that is, the greater the concentration of copper in the water, the greater the tendency for accumulation by the macrophytes (Kabata-Pendias and Pendias, 2001). As well as the concentration, we observed that time is a determining factor both in the accumulation process and in the viability of the plant due to metal toxicity.

The good performance of Salvinia species in the bioaccumulation of metals in different concentrations, as well as an increased absorption over the plant exposure time is known. Salvinia auriculata Aubl. (Salviniaceae) and Eichhornia crassipes (Mart.) Solms (Pontederiaceae) cultivated with different concentrations of arsenic (As), presented metal accumulation proportional to the time of exposure, both in leaf biomass and in roots, however, S. auriculata presented higher values for this accumulation, as well as increased sensitivity to arsenic (Guimarães et al., 2006). The same increase in accumulation with respect to exposure time and concentration of the contaminant was observed in Salvinia sp. for different trace metals (Espinoza-Quiñones et al., 2005).

In this study we showed that S. biloba was effective in copper accumulation in a short period of time. Compared to other species, $S$. biloba shows itself as a more attractive option for phytoremediation programs, since with reduced accumulation time, it is possible to work in the filtering of water systems in a shorter time scale. The greatest care in its use will be the need for the quick removal of the biomass, as a system feedback may occur with the degradation of the plant material. Although it is a very little studied species, it is possible to infer that $S$. biloba presents potential for use as a bio-accumulator, since the accumulation time is an important factor in the phytoremediation process, which makes the species worthwhile for this purpose. 
Macrophytes present varied mechanisms which are favorable to the accumulation of metals, being able to absorb them into their fibrous roots, rhizomes or leaves (Oliveira, 2012). This buildup differs between species and parts of plant tissues (Henares and Camargo, 2014; Kumar et al., 2012). In general, the roots of macrophytes play a key role in the accumulation of substances. For Barros and Henares (2015), this is assertive for floating aquatic weeds, which absorb most of the nutrients through this compartment, with the area and the length of the root being factors which influence the absorption of metal ions. In studies with macrophytes coming from contaminated water systems, the floating species $S$. auriculata and E. crassipes were highlighted by the high levels of mercury $(\mathrm{Hg})$ present in their biomass, mainly in the roots (Molisani et al., 2006). However, Salvinia has a significant uptake of water and nutrients through its leaves, since of course, it maintains its adaxial face in contact with the solution (Rodrigues et al., 2016), and being known to have presented modified leaves which are adapted to absorption (Sculthorpe, 1967). In fact, cadmium absorption values, similar between leaves and roots have been observed in S. auriculata (Oliveira et al., 2001).

It is also possible that retention of metals in some specific tissue occurs, and in this way the bioaccumulation would be a response that is more dependent on the individual than dependent on the population. Further studies testing the bioaccumulation combined with anatomic cuts would be important to determine how the retention of heavy metal takes place, and in this manner, test the hypotheses related to possible occurrence of anomalies in the DNA through gene transfer by sexual reproduction.

In this study, analysis of the leaf biomass and homogenized roots of $S$. biloba showed an elevated accumulation of copper content, especially in the treatment with higher metal concentration. The $S$. biloba control treatment samples had on average $12.43 \mu \mathrm{g} \mathrm{g}^{-1}$ of copper probably originated from the environment in which they were collected, or from the chemical composition of the plants. Elements such as copper are essential for the normal growth and development of plants, however, when present in excess, it becomes toxic and can prevent and inhibit cellular processes (Yruela, 2005) and be considered as one of the most dangerous pollutants to macrophytes in this condition (Kumar et al., 2008). Kabata-Pendias and Pendias (2001) highlighted that copper in plants has a usual concentration of between 5 and $30 \mu \mathrm{g} \mathrm{g}^{-1}$ and toxic limits of between 20 and $100 \mu \mathrm{g} \mathrm{g}^{-1}$.

In addition to the bioaccumulation process, aquatic macrophytes demonstrate applicability when employed in the sorption process for removing different substances present in wastewater (Módenes et al., 2009, 2013; Pelosi et al., 2014; Pietrobelli et al., 2013). The wide distribution, rapid production, adaptability, variety of groups, low cost and the possibility relating to the reusability of the biomass, these plants are attractive and promising species in the remediation of affected environments. And so studies with macrophytes may contribute significantly to the issues related to water resources, especially in the face of widespread problems of scarcity and contamination of surface water, which require urgent and effective solutions. Furthermore, they may respond by various environmental alterations and can be useful as a parameter for monitoring water quality (Rocha et al., 2012).

Some $S$. biloba plants present in all treatments presented changes in color and texture, marginal lesions on the floating leaves, reduction of biomass as well as high mortality, as reported in literature for other Salvinia species (Guimarães et al., 2006; Wolff et al., 2009, 2012). Symptoms like these are typical of the toxicity of metals to macrophytes, some however, may be specific to each species (Guimarães et al., 2012). These authors observed in the Azolla caroliniana Willd. (Azollaceae), Salvinia minima (Salviniaceae) and Lemna gibba L. (Araceae) species specific effects of arsenic toxicity, such as purpling, necrosis and size reduction in the plant leaves. Peixoto et al. (2005) reported the occurrence of morphological lesions in trichomes and adaxial portion of the leaf blade in S. auriculata, inferring a possible oxidative stress in response to fluoride accumulation in the leaves. Root senescence and necrosis in floating leaves were indicated as effects of copper toxicity in Salvinia molesta (Mitchell), responsible for reducing plant biomass (Barros and Henares, 2015).

In general, Salvinia biloba presents potential use as a bioindicator and phytoremediator in aquatic environments contaminated by high copper concentration, above the established by applicable law (Brasil, 2005). The macrophyte performed well in the accumulation of copper in all tested proportions, highlighting the treatment with $5 \mu \mathrm{g} \mathrm{mL}^{-1}$ of the contaminant in which the there was an accumulation about 740-fold higher metal in plant biomass compared to levels found in the initial samples. Accumulation levels were higher in treatments with higher proportions of the component and increased over time of exposure of the plants to the contaminant. The plants showed sensitivity to copper, confirming the toxicity of the metal to the species at high concentrations. Finally, the most important result was the exposure time, because with rapid accumulation, the phytoremediation process should be conducted with caution, as the accumulated metal can feed back into the water system by way of the degradation of plant tissues.

\section{Acknowledgements}

We thank to the Fundação de Amparo à Pesquisa do Estado de Mato Grosso (FAPEMAT) for financial resources (Process Pronex 688844/2010 and 227320/2015), and INCT-CENBAM for logistical aproachs. We thank too Apolônia Grade (Orquídeas da Amazônia, Alta Floresta, MT) that help us in the sampling of aquatic plants to the experiments.

\section{References}

BARROS, J.P.A. and HENARES, M.N.P., 2015. Biomass reduction of Salvinia molesta exposed to copper sulfate pentahydrate 
$\left(\mathrm{CuSO}_{4} \cdot 5 \mathrm{H}_{2} \mathrm{O}\right)$. Revista Ambiente \& Água, vol. 10, no. 3, pp. 520-529. http://dx.doi.org/10.4136/ambi-agua.1633.

BRASIL. Conselho Nacional do Meio Ambiente - CONAMA, 2005. Resolução $n^{\circ}$ 357, de 17 de março de 2005 (Alterada pela Resolução 410/2009 e pela 430/2011). Dispõe sobre a classificação dos corpos d'água e diretrizes ambientais para o seu enquadramento, bem como estabelece as condições e padrões de lançamento de efluentes, e dá outras providências. Diário Oficial da República Federativa do Brasil, Brasília, 17 mar. pp. 58-63.

DHIR, B., SHARMILA, P. and SARADHI, P.P., 2008. Photosynthetic performance of Salvinia natans exposed to chromium and zinc rich wastewater. Brazilian Journal of Plant Physiology, vol. 20, no. 1, pp. 61-70. http://dx.doi.org/10.1590/S1677-04202008000100007.

ESPINOZA-QUIÑONES, F.R., ZACARKIM, C.E., PALACIO, S.M., OBREGÓN, C.L., ZENATTI, D.C., GALANTE, R.M., ROSSI, N., ROSSI, F.L., PEREIRA, I.R.A., WELTER, R.A. and RIZZUTTO, M.A., 2005. Removal of heavy metal from polluted river water using aquatic macrophytes Salvinia sp. Brazilian Journal of Physics, vol. 35, no. 3b, pp. 744-746. http://dx.doi. org/10.1590/S0103-97332005000500005.

ESTEVES, F.A., 1998. Fundamentos de Limnologia. 2nd ed. Rio de Janeiro: Interciência/FINEP.

FARNESE, F.S., OLIVEIRA, J.A., LIMA, F.S., LEÃO, G.A., GUSMAN, G.S. and SILVA, L.C., 2014. Evaluation of the potential of Pistia stratiotes L. (water lettuce) for bioindication and phytoremediation of aquatic environments contaminated with arsenic. Brazilian Journal of Biology $=$ Revista Brasileira de Biologia, vol. 74, no. 3, suppl. 1, pp. 103-112. http://dx.doi. org/10.1590/1519-6984.01113. PMid:25627371.

FRANÇA, J.B.A., MORAES, T.V., VAZ, D.C., FERREIRA, A.A. and SOARES, F.A.L., 2014. Tratamento de efluente doméstico com macrófitas aquáticas para reuso na fertirrigação. Brazilian Journal of Irrigation and Drainage, vol. 1, pp. 85-93. http:// dx.doi.org/10.15809/irriga.2014v1n1p85.

GUIMARÃES, F.P., AGUIAR, R., OLIVEIRA, J.A., SILVA, J.A.A. and KARAM, D., 2012. Potential of macrophyte for removing arsenic from aqueous solution. Planta Daninha, vol. 30, no. 4, pp. 683-696. http://dx.doi.org/10.1590/S0100-83582012000400001.

GUIMARÃES, F.P., GOMES, C.Q., MAGALHÃES, A.B.S., FREITAS, T.V., OLIVEIRA, J.A. and AGUIAR, R., 2006. Estudos laboratoriais de acúmulo e toxicidade de arsênio em Eichhornia crassipes e Salvinia auriculata. Journal of the Brazilian Society of Ecotoxicology, vol. 2, no. 2, pp. 109-113. http://dx.doi. org/10.5132/jbse.2006.02.003.

HENARES, M.N.P. and CAMARGO, A.F.M., 2014. Treatment efficiency of effluent prawn culture by wetland with floating aquatic macrophytes arranged in series. Brazilian Journal of Biology $=$ Revista Brasileira de Biologia, vol. 74, no. 4, pp. 906912. PMid:25627602. http://dx.doi.org/10.1590/1519-6984.10413.

HSEU, Z.Y., 2004. Evaluating heavy metal contents in nine composts using four digestion methods. Bioresource Technology, vol. 95, no. 1, pp. 53-59. PMid:15207295. http://dx.doi.org/10.1016/j. biortech.2004.02.008.

KABATA-PENDIAS, A. and PENDIAS, H., 2001. Trace elements in soils and plants. 3rd ed. New York: Taylor \& Francis Group.

KUMAR, N., BAUDDH, K., DWIVEDI, E., BARMAN, S.C. and SINGH, D.P., 2012. Accumulation of metals in selected macrophytes grown in mixture of drain water and tannery effluent and their phytoremediation potential. Journal of Environmental Biology, vol. 33, no. 5, pp. 923-927. PMid:23734460.

KUMAR, N.I.J., SONI, H., KUMAR, R.N. and BHATT, I., 2008. Macrophytes in phytoremediation of heavy metal contaminated water and sediments in Pariyej Community Reserve, Gujarat, India. Turkish Journal of Fisheries and Aquatic Sciences, vol. 8, pp. 193-200

MARONEZE, M.M., ZEPKA, L.K., VIEIRA, J.G., QUEIROZ, M.I. and JACOB-LOPES, E., 2014. A tecnologia de remoção de fósforo: Gerenciamento do elemento em resíduos industriais. Revista Ambiente \& Água, vol. 9, no. 3, pp. 445-458. http://dx.doi. org/10.4136/ambi-agua.1403.

MEDEIROS, J.C., COELHO, F.F. and TEIXEIRA, E., 2016. Biomass allocation and nutrients balance related to the concentration of Nitrogen and Phosphorus in Salvinia auriculata (Salviniaceae). Brazilian Journal of Biology $=$ Revista Brasileira de Biologia, vol. 76, no. 2, pp. 461-468. PMid:26959946. http://dx.doi. org/10.1590/1519-6984.21114.

MÓDENES, A.N., PIETROBELLI, J.M.T.A., QUIÑONES, F.R.E., SUZAKI, P.Y.R., ALFLEN, V.L. and KLEN, M.R.S., 2009. Biosorption potential of zinc by Egeria dense macrophytes. Engenharia Sanitaria e Ambiental, vol. 14, no. 4, pp. 465-470. http://dx.doi.org/10.1590/S1413-41522009000400006.

MÓDENES, A.N., ROSS, A.A., SOUZA, B.V., DOTTO, J., GERALDI, C.Q., QUIÑONES, F.R.E. and KROUMOV, A.D., 2013. Biosorption of BF-4B reactive red dye by using leaves of macrophytes Eichhornia crassipes. International Journal Bioautomation, vol. 17, no. 1, pp. 33-44.

MOLISANI, M.M., ROCHA, R., MACHADO, W., BARRETO, R.C. and LACERDA, L.D., 2006. Mercury contents in aquatic macrophytes from two reservoirs in the Paraíba do Sul: Guandú river system, SE, Brazil. Brazilian Journal of Biology $=$ Revista Brasileira de Biologia, vol. 66, no. 1A, pp. 101-107. PMid:16680311. http://dx.doi.org/10.1590/S1519-69842006000100013.

OLIVEIRA, A.P., 2012. Avaliação da influência dos macronutrientes na bioacumulação de chumbo pela Eichhornia crassipes. Toledo: Universidade Estadual do Oeste do Paraná, 134 p. Dissertação de Mestrado em Desenvolvimento de Processos.

OLIVEIRA, J.A., CAMBRAIA, J., CANO, M. and JORDÃO, C.P., 2001. Absorção e acúmulo de cádmio e seus efeitos sobre o crescimento relativo de plantas de Salvinia sp. e aguapé. Brazilian Journal of Plant Physiology, vol. 13, no. 3, pp. 329-341. http:// dx.doi.org/10.1590/S0103-31312001000300008.

PEIXOTO, P.H.P, PIMENTA, D.S. and ANTUNES, F., 2005. Fluoride effects on leaves of aquatic Salvinia auriculata. Revista de Pesquisa Agropecuária Brasileira, vol. 40, no. 8, pp. 727-734. http://dx.doi.org/10.1590/S0100-204X2005000800001.

PELOSI, B.T., LIMA, L.K.S. and VIEIRA, M.G.A., 2014. Removal of the synthetic dye Remazol Brilliant Blue R from textile industry wastewaters by biosorption on the macrophyte Salvinia natans. Brazilian Journal of Chemical Engineering, vol. 31, no. 4, pp. 1035-1045. http://dx.doi.org/10.1590/0104$6632.20140314 \mathrm{~s} 00002568$.

PIETROBELLI, J.M.T.A., CORRÊA, A.R., LEICHTWEIS, W.A., PIETROBELLI, S., MÓDENES, A.N., TRIGUEROS, D.E., QUIÑONES, F.R.E. and RAVAGNANI, R.A.S., 2013. Avaliação do potencial de biossorção dos íons $\mathrm{Cd}$ (II), $\mathrm{Cu}$ (II) e Zn (II) pela macrófita Egeria densa. Revista Brasileira de Ciências Ambientais, vol. 28, pp. 1-9. 
PIO, M.C.S., SOUZA, K.S. and SANTANA, P.S., 2013. Capacidade da Lemna aequinoctialis para acumular metais pesados de água contaminada. Acta Amazonica, vol. 43, no. 2, pp. 203-210. http:// dx.doi.org/10.1590/S0044-59672013000200011.

PITELLI, R.L.C.M., PITELLI-MERENDA, A.M.C.M., PITELLI, R.A., SIQUEIRA, R.C., BARBOSA, H.O. and JESUS, L., 2014. Composição específica e distribuição da comunidade de macrófitas aquáticas no reservatório de aimorés. Planta Daninha, vol. 32, no. 3, pp. 475-482. http://dx.doi.org/10.1590/S010083582014000300002 .

PITOL-FILHO, L., 2011. Sustainable applications of biomass: New perspectives. Revista da Unifebe, vol. 9, pp. 100-109.

POMPEO, M., 2008. Monitoramento e manejo de Macrófitas aquáticas. Oecologia Brasiliensis, vol. 12, no. 3, pp. 406-424.

POTT, V.J. and POTT, A., 1997. Checklist das macrófitas aquáticas do Pantanal, Brasil. Acta Botanica Brasílica, vol. 11, no. 2, pp. 215-227. http://dx.doi.org/10.1590/S0102-33061997000200010.

POTT, V.J., POTT, A., LIMA, L.C.P., MOREIRA, S.N. and OLIVEIRA, A.K.M., 2011. Aquatic macrophyte diversity of the Pantanal wetland and upper basin. Brazilian Journal of Biology = Revista Brasileira de Biologia, vol. 71, no. 1, suppl. 1, pp. 255-263. PMid:21537598. http://dx.doi.org/10.1590/S151969842011000200004 .

PRADO, J., 2006. Criptógamos do Parque Estadual das Fontes do Ipiranga, São Paulo, SP, Pteridophyta: Salviniaceae. Hoehnea, vol. 33 , no. 1 , pp. 107-110.

R CORE TEAM, 2014. [viewed 8 July 2016] $R$ : A language and environment for statistical computing. $\mathrm{R}$ Foundation for Statistical Computing: Vienna. [online]. Available from: http:// www.R-project.org/

ROCHA, C.M.C., ALVES, A.E., CARDOSO, A.S. and CUNHA, M.C.C., 2012. Macrófitas aquáticas como parâmetro no monitoramento ambiental da qualidade da água. Revista Brasileira de Geografia Física, vol. 4, pp. 970-983.
RODRIGUES, A.C.D., SANTOS, A.M., SANTOS, F.S., PEREIRA, A.C.C. and SOBRINHO, N.M.B.A., 2016. Mecanismos de respostas das plantas à poluição por metais pesados: Possibilidade de uso de macrófitas para remediação de ambientes aquáticos contaminados. Revista Virtual Química, vol. 8, no. 1, pp. 262-276. http://dx.doi. org/10.5935/1984-6835.20160017.

SCHNEIDER, I.A.H., RUBIO, J. and SMITH, R.W., 2011. Biosorption of metals onto plant biomass: Exchange adsorption or surface precipitation? International Journal of Mineral Processing, vol. 62, no. 1-4, pp. 111-120. http://dx.doi.org/10.1016/S03017516(00)00047-8.

SCULTHORPE, C.D., 1967. The biology of aquatic vascular plants. 1st ed. London: Edward Arnold.

SILVA, J.L.B.C., PEQUENO, O.T.B.L., ROCHA, L.K.Y.S., ARAÚJO, E.C.O.A., MARCIEL, T.A.R. and BARROS, A.J.M.B., 2014. Biossorção de metais pesados: uma revisão. Revista Saúde e Ciência, vol. 3, no. 3, pp. 137-149.

TRYON, R.M. and TRYON, A.F., 1982. Ferns and allied plants, with special reference to Tropical America. 1st ed. New York: Springer Verlag.

WOLFF, G., ASSIS, L.R., PEREIRA, G.C., CARVALHO, J.G. and CASTRO, E.M., 2009. Efeitos da toxicidade do zinco em folhas de Salvinia auriculata cultivadas em solução nutritiva. Planta Daninha, vol. 27, no. 1, pp. 133-137. http://dx.doi.org/10.1590/ S0100-83582009000100017.

WOLFF, G., PEREIRA, G.C., CASTRO, E.M., LOUZADA, J. and COELHO, F.F., 2012. The use of Salvinia auriculata as a bioindicator in aquatic ecosystems: Biomass and structure dependent on the cadmium concentration. Brazilian Journal of Biology $=$ Revista Brasileira de Biologia, vol. 72, no. 1, pp. 71-77. PMid:22437387. http://dx.doi.org/10.1590/S151969842012000100009 .

YRUELA, I., 2005. Copper in plants. Brazilian Journal of Plant Physiology, vol. 17, no. 1, pp. 145-156. http://dx.doi.org/10.1590/ S1677-04202005000100012. 